\title{
Supernumerary renal vessels: analysis of frequency and configuration in 996 computed tomography studies
}

\author{
G. Staśkiewicz ${ }^{1}{ }^{2}$, K. Jajko ${ }^{1}$, K. Torres ${ }^{1}$, E. Czekajska-Chehab², R. Maciejewski ${ }^{1}$, A. Drop ${ }^{2}$ \\ ${ }^{1}$ Human Anatomy Department, Medical University of Lublin, Poland \\ $21^{\text {st }}$ Department of Radiology, Medical University of Lublin, Poland
}

[Received: 1 June 2015; Accepted: 13 July 2015]

Background: Number, course and division pattern of renal vessels is highly variable. Variant renal vasculature is of high interest in nephrectomy for the renal transplantations, both in deceased and living donors. The purpose of the study was to analyse the frequency of supernumerary renal vessels in a large cohort of patients undergoing the multiphase abdominopelvic computed tomography (CT), as well as analyse the possible patterns of coexisting supernumerary arteries in veins. Materials and methods: A retrospective analysis of abdominopelvic CT studies within 1 year period was performed. In each study, number of renal arteries and veins was recorded. Course of left renal vein was classified into normal, retro- or periaortic. For statistical analysis of normal distribution data, t-Student test was used. Chi-square test was used for frequency of variant vessel distribution. Pearson correlation coefficient was used for the analysis of coexistence of supernumerary vessels.

Results: 996 patients were included in the analysis, male to female ratio: 481:515 (48\%:52\%). Mean age was $57.9 \pm 14.7$ years. Single renal arteries were observed in $73 \%$ of cases, while single renal veins in $95 \%$. Circumaortic or retroaortic courses of left renal veins were observed in $10 \%$ of cases. Number of renal vessels has been compared in patients with and without supernumerary vessels. In patients with supernumerary left renal artery, significantly more right renal vessels were observed. In patients with supernumerary right renal vein, mean number of all remaining vessels was significantly higher.

Conclusions: Supernumerary renal vessels are a frequent finding in abdominal CT studies. Finding a supernumerary vessel should increase awareness of possible other supernumerary renal vessels. (Folia Morphol 2016; 75, 2: 245-250)

Key words: renal vessels, anomalies, supernumerary vessels, computed tomography

\section{INTRODUCTION}

Number, course and division pattern of renal vessels is highly variable [1, 12]. Even the first modern depictions of renal anatomy by Bartolomeo Eustachii [10] show supernumerary renal vessels. The classical concept of single renal arteries and veins should be carefully reviewed, in particular in planning the renal surgery: variant renal vasculature is of particular interest in nephrectomy for the renal transplantations, both in deceased and living donors. With the 
Table 1. Number of renal arteries in 996 analysed patients

\begin{tabular}{lccccc}
\hline \multirow{2}{*}{$\begin{array}{l}\text { Number } \\
\text { of vessels }\end{array}$} & \multicolumn{2}{c}{ Females } & & \multicolumn{2}{c}{ Males } \\
\cline { 2 - 3 } \cline { 5 - 6 } \cline { 5 - 6 } & Left artery & Right artery & & Left artery & Right artery \\
\hline 1 & $365(70.9 \%)$ & $389(75.5 \%)$ & & $352(73.2 \%)$ & $346(71.9 \%)$ \\
2 & $142(27.6 \%)$ & $121(23.5 \%)$ & & $123(25.6 \%)$ & $126(26.2 \%)$ \\
4 & $7(1.4 \%)$ & $5(1.0 \%)$ & & $6(1.2 \%)$ & $9(1.9 \%)$ \\
4 & $1(0.2 \%)$ & $0(0 \%)$ & & $0(0 \%)$ & $0(0 \%)$ \\
\hline
\end{tabular}

Table 2. Number of renal veins in 996 analysed patients

\begin{tabular}{lccccc}
\hline \multirow{2}{*}{$\begin{array}{l}\text { Number } \\
\text { of vessels }\end{array}$} & \multicolumn{2}{c}{ Females } & & \multicolumn{2}{c}{ Males } \\
\cline { 2 - 3 } \cline { 5 - 6 } & Left vein & Right vein & & Left vein & Right vein \\
\hline 1 & $490(95.1 \%)$ & $468(90.9 \%)$ & & $459(95.4 \%)$ & $430(89.4 \%)$ \\
2 & $25(4.9 \%)$ & $46(8.9 \%)$ & & $22(4.6 \%)$ & $51(10.6 \%)$ \\
3 & $0(0 \%)$ & $1(0.2 \%)$ & & $0(0 \%)$ & $0(0 \%)$ \\
\hline
\end{tabular}

development of minimally invasive nephrectomy, the importance of imaging methods for identification of renal vessels became crucial to improve the safety and feasibility of laparoscopic procedures. Nowadays, multiple renal arteries are no longer relative contraindication for laparoscopic donor nephrectomy: however, awareness of their presence may help avoid possible complications $[5,6]$.

Embryologically, the formation of inferior vena cava and renal veins occurs between 4 and 8 gestational weeks. Their development includes evolution of 3 paired veins: posterior cardinal, subcardinal and supracardinal veins [17]. Ascent of kidneys into the lumbar region between 6 and 9 gestational week results with their subsequent temporary supply by 9 pairs of arteries originating from dorsal aorta. These arteries are divided into 3 groups: cranial, middle and caudal. Main renal artery is formed from the second or third group of mesonephric arteries, while persistent arteries of other groups may provide supernumerary renal arteries [3].

The purpose of the study was to analyse the frequency of supernumerary renal vessels in a large cohort of patients undergoing the multiphase abdominopelvic computed tomography (CT), as well as analyse the patterns of coexisting supernumerary arteries and veins.

\section{MATERIALS AND METHODS}

A retrospective analysis of multiphase abdominopelvic CT studies at our institution within 1-year peri- od was performed. Patients with insufficient contrast enhancement of renal vessels, single, transplanted or horseshoe kidneys were excluded from further analysis. In each study, number of renal arteries and veins was recorded. Course of left renal vein was classified into normal, retro- or periaortic. All CT studies were analysed with Advantage 4.2 Workstation (GE Medical Systems). Statistical analysis has been performed to compare frequency of variant vessels in males and females. For normal distribution data, t-Student test was used. Chi-square test was used for frequency of variant vessel distribution. Pearson correlation coefficient was used for the analysis of coexistence of supernumerary vessels. All statistical analyses have been performed with SPSS 16.0 statistical package.

\section{RESULTS}

Nine hundred ninety six patients were included in the analysis, male to female ratio: $481: 515$ (48\%:52\%). Mean age was $57.9 \pm 14.7$ years. No significant difference of age in males and females was observed. Single renal arteries were observed on the left side in $71.9 \%$ and in $73.8 \%$ on the right side. Single renal veins were found in $95.3 \%$ of patients on the left, and $90.2 \%$ on the right side. Distribution of number of renal vessels in the study groups is presented in Tables 1 and 2. Summarised frequency of supernumerary vessels in males and females is presented in Table 3 and Figure 1. No significant differences between males and females were observed. 
Table 3. Gender distribution of supernumerary vessels. No significant difference of frequencies between males and females were observed $\left(\chi^{2}=0.625 ; p=0.89\right)$

\begin{tabular}{lcc}
\hline & Females & Males \\
\hline Supernumerary left artery & $150(29.2 \%)$ & $129(26.8 \%)$ \\
Supernumerary right artery & $126(24.5 \%)$ & $135(28.1 \%)$ \\
Supernumerary left vein & $25(4.9 \%)$ & $22(4.6 \%)$ \\
Supernumerary right vein & $47(9.1 \%)$ & $51(10.6 \%)$ \\
\hline
\end{tabular}

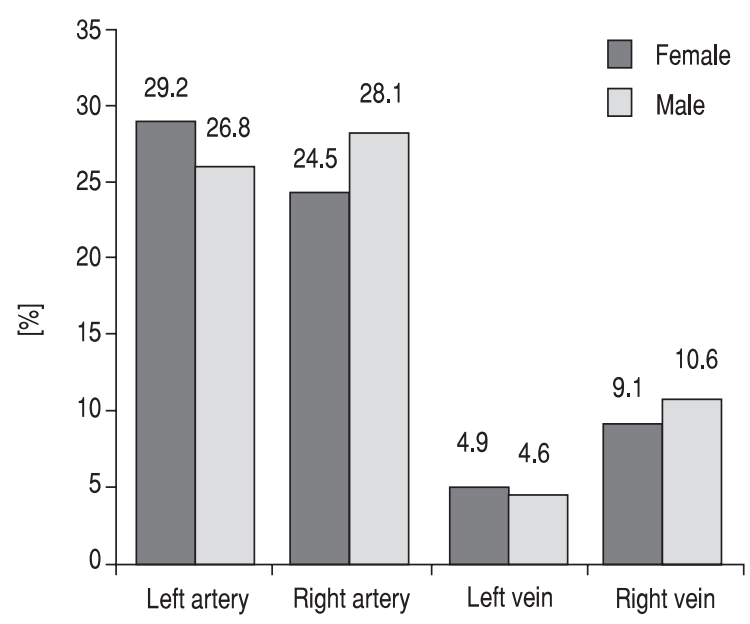

Figure 1. Frequency of supernumerary renal vessels in males and females. No significant difference of frequencies between males and females were observed $\left(\chi^{2}=0.625 ; p=0.89\right)$.
Bilateral supernumerary renal arteries were observed in 114 (11.4\%) patients of the population (Figs. 2, 3).

For the left renal vein, the course was classified as normal, retroaortic or circumaortic. The distribution of particular types among sexes is presented in Table 4. No significant difference of the type of renal vein was observed between males and females $\chi^{2}=1.22$, $p=0.543)$.

An analysis of correlation of number of renal vessels was performed to assess the possible tendency of concomitant occurrence of supernumerary vessels. Results of the analysis are presented in Table 5. All significant correlations are positive, which confirms the tendency for concomitance in supernumerary vessels (Fig. 4), although all observed correlations are weak.

To confirm the observed correlations, number of renal vessels has been compared in patients with and without supernumerary vessels. In patients with supernumerary left renal artery, significantly more right renal vessels were observed. In patients with supernumerary right renal vein, mean number of all remaining vessels was significantly higher. Detailed results are presented in Tables 6 and 7.

\section{DISCUSSION}

Multidetector CT has a high accuracy of detection of anomalous renal vasculature, ranging from $95 \%$

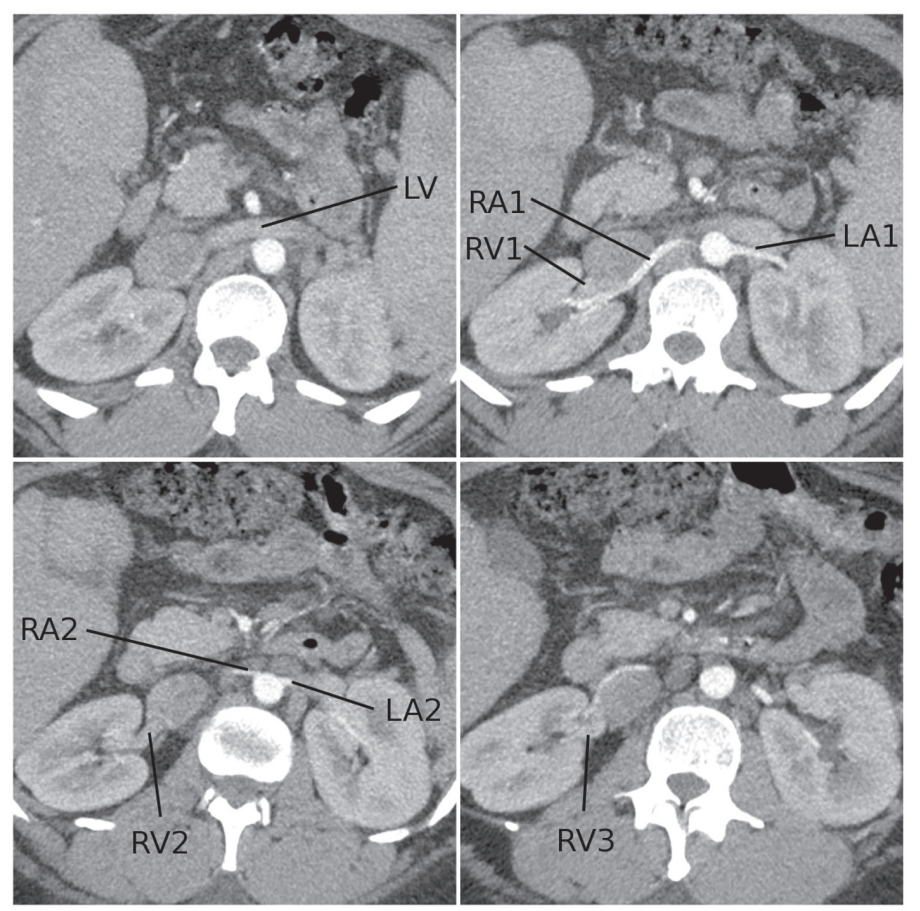

Figure 2. Maximum intensity axial projection in patient with bilateral two renal arteries and triple right renal vein; RA — right renal artery; LA — left renal artery; RV — right renal vein; LV — left renal vein. 


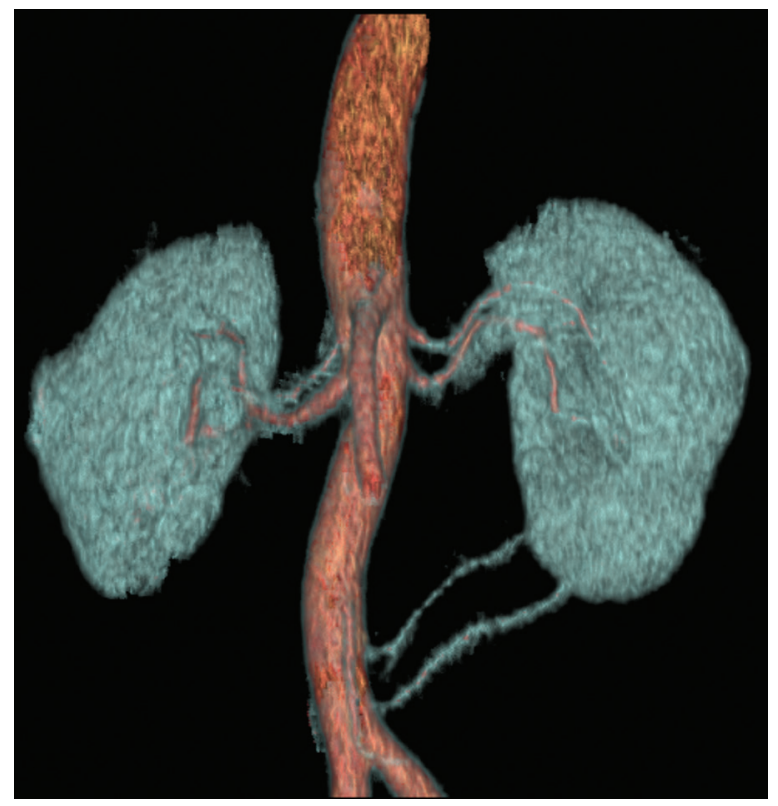

Figure 3. Volume rendering arterial phase reconstruction in patient with two arteries of the right, and four arteries of the left kidney.

Table 4. Configuration of left renal vein in 996 analysed patients. No significant difference of frequencies between males and females were observed $\left(\chi^{2}=0.528 ; p=0.77\right)$

\begin{tabular}{lcc}
\hline & Females & Males \\
\hline Normal & $461(89.5 \%)$ & $439(91.3 \%)$ \\
Circumaortic & $25(4.9 \%)$ & $22(4.6 \%)$ \\
Retroaortic & $29(5.6 \%)$ & $20(4.2 \%)$ \\
\hline
\end{tabular}

to $100 \%[2,14]$. Noninvasive diagnosis of variant renal vasculature has become of high importance with the development of minimally invasive renal nephrectomy [4, 8, 9].

In the studied patients, supernumerary right renal veins were more frequent than the left ones. This is con-

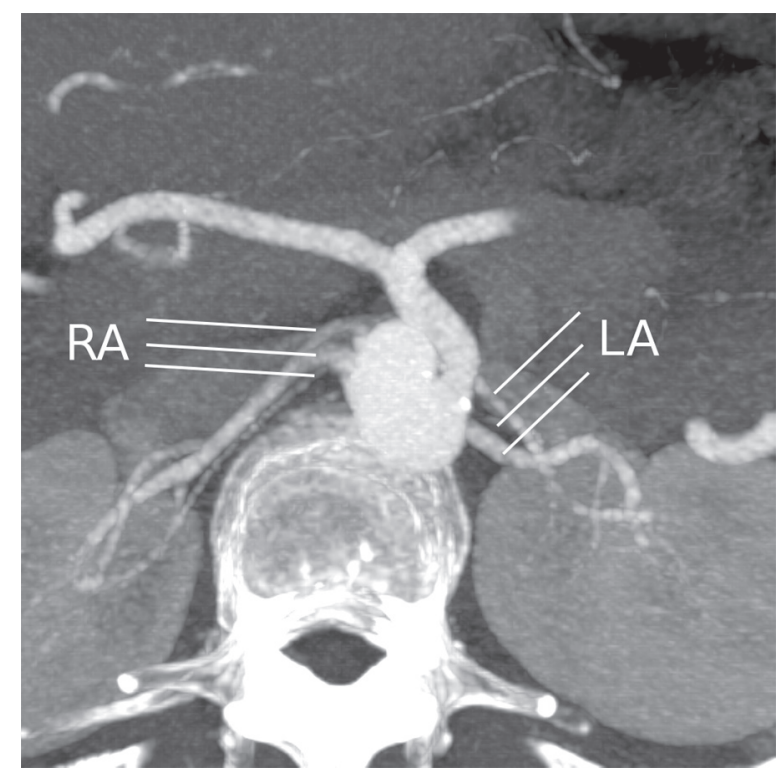

Figure 4. Maximum intensity axial projection in patient with bilateral triple renal arteries; LA — left renal artery; RA — right renal artery.

firmed by recent analysis of Zhu et al. [20], who observed right renal vein variations in $19.2 \%$, and left renal vein variations in $7.1 \%$ of their population, with supernumerary veins on the left found in $2.7 \%$ and $18.7 \%$ on the right side. Similarly, Janschek et al. [7] report more common variations on the right side (23\%) than on the left (6.7\%). Ozkan et al. [11] have observed single left renal artery in $86 \%$ of their 855 angiography patients, and single right one in $83 \%$ of patients, which is more frequent than in our group. According to Saldarriaga et al. [13], high frequency of supernumerary renal arteries is reported in Caucasian and African (30-40\%), as opposed to Indian population (13.5\%). Similar to our results, Saldarriaga et al. [13] did not observe gender differences in frequency of supernumerary arteries. Frequency of circumaortic left renal vein in our population was $4.72 \%$, which fits its

Table 5. Results of Pearson correlation (PC) analysis of renal vessels numbers

\begin{tabular}{llcccc}
\hline & & Left artery & Right artery & Left vein & Right vein \\
\hline \multirow{2}{*}{ Left artery } & PC & 1 & $\mathbf{0 . 0 9 4}$ & 0.001 & $\mathbf{0 . 1 0 7}$ \\
& $\mathrm{P}$ & - & $\mathbf{0 . 0 0 3}$ & 0.969 & $\mathbf{0 . 0 0 1}$ \\
\hline \multirow{2}{*}{ Right artery } & $\mathrm{PC}$ & $\mathbf{0 . 0 9 4}$ & 1 & -0.049 & $\mathbf{0 . 0 6 7}$ \\
& $\mathrm{P}$ & $\mathbf{0 . 0 0 3}$ & - & 0.12 & $\mathbf{0 . 0 3 4}$ \\
\hline \multirow{2}{*}{ Left vein } & $\mathrm{PC}$ & 0.001 & -0.049 & 1 & $\mathbf{0 . 1 1 5}$ \\
& $\mathrm{P}$ & 0.969 & 0.12 & - & $\mathbf{0 . 0 0 1}$ \\
\hline \multirow{2}{*}{ Right vein } & PC & $\mathbf{0 . 1 0 7}$ & $\mathbf{0 . 0 6 7}$ & $<\mathbf{0 . 0 0 1}$ & - \\
\hline
\end{tabular}


Table 6. Mean number of renal vessels in patients with and without supernumerary renal arteries

\begin{tabular}{|c|c|c|c|c|c|c|c|c|c|c|}
\hline & $\begin{array}{l}\text { Supernumerary } \\
\text { left renal artery }\end{array}$ & $\mathbf{N}$ & Mean & $\begin{array}{l}\text { Standard } \\
\text { deviation }\end{array}$ & $\mathbf{P}$ & $\begin{array}{c}\text { Supernumerary } \\
\text { right renal artery }\end{array}$ & $\mathbf{N}$ & Mean & $\begin{array}{l}\text { Standard } \\
\text { deviation }\end{array}$ & $\mathbf{P}$ \\
\hline \multirow{2}{*}{ Left artery } & Yes & 279 & 2.05 & 0.24 & \multirow{2}{*}{$<0.001$} & Yes & 261 & 1.35 & 0.54 & \multirow{2}{*}{0.08} \\
\hline & No & 717 & 1 & 0 & & No & 735 & 1.28 & 0.47 & \\
\hline \multirow{2}{*}{ Right artery } & Yes & 279 & 1.33 & 0.54 & \multirow{2}{*}{0.03} & Yes & 261 & 2.05 & 0.23 & \multirow{2}{*}{$<0.001$} \\
\hline & No & 717 & 1.26 & 0.45 & & No & 735 & 1 & 0 & \\
\hline \multirow{2}{*}{ Left vein } & Yes & 279 & 1.05 & 0.22 & \multirow{2}{*}{0.78} & Yes & 261 & 1.03 & 0.17 & \multirow{2}{*}{0.14} \\
\hline & No & 717 & 1.05 & 0.21 & & No & 735 & 1.05 & 0.22 & \\
\hline \multirow{2}{*}{ Right vein } & Yes & 279 & 1.15 & 0.37 & \multirow{2}{*}{$<0.001$} & Yes & 261 & 1.13 & 0.34 & \multirow{2}{*}{0.09} \\
\hline & No & 717 & 1.08 & 0.27 & & No & 735 & 1.09 & 0.29 & \\
\hline
\end{tabular}

Table 7. Mean number of renal vessels in patients with and without supernumerary renal veins

\begin{tabular}{|c|c|c|c|c|c|c|c|c|c|c|}
\hline & $\begin{array}{l}\text { Supernumerary } \\
\text { left renal vein }\end{array}$ & $\mathbf{N}$ & Mean & $\begin{array}{l}\text { Standard } \\
\text { deviation }\end{array}$ & $\mathbf{P}$ & $\begin{array}{l}\text { Supernumerary } \\
\text { right renal vein }\end{array}$ & $\mathbf{N}$ & Mean & $\begin{array}{l}\text { Standard } \\
\text { deviation }\end{array}$ & $\mathbf{P}$ \\
\hline \multirow{2}{*}{ Left artery } & Yes & 47 & 1.29 & 0.462 & \multirow{2}{*}{0.97} & Yes & 98 & 1.45 & 0.54 & \multirow{2}{*}{$<0.001$} \\
\hline & No & 949 & 1.30 & 0.492 & & No & 898 & 1.28 & 0.48 & \\
\hline \multirow{2}{*}{ Right artery } & Yes & 47 & 1.17 & 0.38 & \multirow{2}{*}{0.12} & Yes & 98 & 1.37 & 0.56 & \multirow{2}{*}{0.04} \\
\hline & No & 949 & 1.28 & 0.482 & & No & 898 & 1.27 & 0.47 & \\
\hline \multirow{2}{*}{ Left vein } & Yes & 47 & 2.0 & 0 & \multirow{2}{*}{$<0.001$} & Yes & 98 & 1.12 & 0.33 & \multirow{2}{*}{$<0.001$} \\
\hline & No & 949 & 1.0 & 0 & & No & 898 & 1.04 & 0.19 & \\
\hline \multirow{2}{*}{ Right vein } & Yes & 47 & 1.26 & 0.441 & \multirow{2}{*}{$<0.001$} & Yes & 98 & 2.01 & 0.10 & \multirow{2}{*}{$<0.001$} \\
\hline & No & 949 & 1.09 & 0.292 & & No & 898 & 1 & 0 & \\
\hline
\end{tabular}

reported range from $2 \%$ to $17 \%$ [18]. Bilateral supernumerary renal arteries were found in $11.4 \%$ of our patients, which is similar to the frequency of $6-15 \%$ reported in the literature $[15,16,19]$. Presented data show, that presence of supernumerary renal vessel should raise the concern of possible concomitant vascular anomalies: in patients with supernumerary left renal artery, significantly more right renal vessels were observed, while in patients with supernumerary right renal vein, mean number of all remaining vessels was significantly higher. Application of multidetector CT allows for the simultaneous analysis of renal arteries and veins, which may provide significant preoperative information on the pattern of renal vasculature.

\section{CONCLUSIONS}

Supernumerary renal vessels are a frequent finding in abdominal CT studies. Finding a supernumerary vessel should increase awareness of possible other supernumerary renal vessels.

\section{REFERENCES}

1. Awojobi OA, Ogunbiyi OA, Nkposong EO (1983) Unusual relationship of multiple renal arteries. Urology, 21: 205-206.

2. Chai JW, Lee W, Yin YH, Jae HJ, Chung JW, Kim HH, Park JH (2008) CT angiography for living kidney donors: accuracy, cause of misinterpretation and prevalence of variation. Kor J Radiol, 9: 333-339.

3. Felix W (1912) Mesonephric arteries (aa. mesonephrica). In: Keibel F, Mall FP eds. Manual of human embryology. Vol. 2. Lippincott, Philadelphia, PA, USA, pp. 681-685; 820-825.

4. He B, Hamdorf JM (2013) Clinical importance of anatomical variations of renal vasculature during laparoscopic donor nephrectomy. OA Anatomy, 1: 25.

5. Hung CJ, Lin YJ, Chang SS, Chou TC, Lee PC (2012) Kidney grafts with multiple renal arteries is no longer a relative contraindication with advance in surgical techniques of laparoscopic donor nephrectomy. Transplant Proc, 44: 36-38.

6. Husted TL, Hanaway MJ, Thomas MJ, Woodle ES, Buell JF (2005) Laparoscopic living donor nephrectomy for kidneys with multiple arteries. Transplant Proc, 37: 629-630.

7. Janschek EC, Rothe AU, Hölzenbein TJ, Langer F, Brugger PC, Pokorny H, Domenig CM, Rasoul-Rockenschaub S, Mühlbacher $F$ (2004) Anatomic basis of right renal vein extension for cadaveric kidney transplantation. Urology, 63: 660-664. 
8. Kawamoto S, Montgomery RA, Lawler LP, Horton KM, Fishman EK (2004) Multi-detector row CT evaluation of living renal donors prior to laparoscopic nephrectomy. Radiographics, 24: 453-466.

9. Kim JK, Park SY, Kim HJ, Kim CS, Ahn HJ, Ahn TY (2003) Living donor kidneys: usefulness of multi-detector row CT for comprehensive evaluation. Radiology, 229: 869-876.

10. Lancisi GM (1714) Tabulae anatomicae Bartolomaei Eustachii. Ex officina typografia Francisci Gonzagae, Rome.

11. Ozkan U, Oğuzkurt L, Tercan F, Kizilkiliç O, Koç Z, Koca N (2006) Renal artery origins and variations: angiographic evaluation of 855 consecutive patients. Diagn Interv Radiol, 12: 183-186.

12. Patil UD, Ragavan A, Nadaraj, Murthy $K$, Shankar R, Bastani B, Ballal SH (2001) Helical CT angiography in evaluation of live kidney donors. Nephrol Dial Transplant, 16: 1900-1904.

13. Saldarriaga B, Pérez AF, Ballesteros LE (2008) A direct anatomical study of additional renal arteries in a Colombian mestizo population. Folia Morphol, 67: 129-134.

14. Schlunt LB, Harper JD, Broome DR, Baron PW, Watkins GE, Ojogho ON (2007) Improved detection of renal vascular anatomy using multidetector CT angiography: is $100 \%$ detection possible? J Endourol, 21: 12-17.

15. Spring DB, Salvatierra O Jr, Palubinskas AJ, Amend WJ Jr, Vincenti FG, Feduska NJ (1979) Results and significance of angiography in potential kidney donors. Radiology, 133: 45-47.

16. Talovic E, Kulenovic A, Voljevica A, Ovcina F, Prevljak S (2004) Angiographic imaging of supernumerary kidney arteries by nonselective angiography. Med Arh, 58: 263-267.

17. Tore HG, Tatar I, Celik HH, Oto A, Aldur MM, Denk CC (2005) Two cases of inferior vena cava duplication with their $\mathrm{CT}$ findings and a review of the literature. Folia Morphol, 64: 55-58.

18. Trigaux JP, Vandroogenbroek S, De Wispelaere JF, Lacrosse M, Jamart J (1998) Congenital anomalies of the inferior vena cava and left renal vein: evaluation with spiral CT. J Vasc Intervent Radiol, 9: 339-345.

19. Vilhova I, Kryvko Y, Maciejewski R (2001) The radioanatomical research of plural renal arteries. Folia Morphol, 60: 337-341.

20. Zhu J, Zhang L, Yang Z, Zhou H, Tang G (2015) Classification of the renal vein variations: a study with multidetector computed tomography. Surg Radiol Anat, 2015; 37: 667-675. 